\title{
Effect of copper on the activation of the acid phosphatase from the green algae Pseudokirchneriella subcapitata
}

\author{
Claudio Martín Jonsson · Hiroshi Aoyama
}

Received: 13 March 2009/Accepted: 9 September 2009/Published online: 19 September 2009

(C) Springer Science+Business Media, LLC. 2009

\begin{abstract}
The presence of copper in water environment may have detrimental effects on aquatic organisms, including algae, where different enzymatic systems can be affected. Algae acid phosphatase plays important roles in metabolic processes such as decomposition of organic phosphate, autophagic digestive process, recycling cellular materials and zygote formation during reproduction. This work describes an in vitro activation effect of copper on the acid phosphatase of the green algae Pseudokirchneriella subcapitata (formely Selenastrum capricornutum) under preincubation condition. Apparent Michaelis constant values of 1.21 and $0.37 \mathrm{mM}$, and activation energy values of 26.8 and $13.6 \mathrm{~kJ} \mathrm{~mol}^{-1}$ were determined in the absence and in the presence of $0.2 \mathrm{mM} \mathrm{Cu}^{2+}$, respectively. The dissociation constant value for $\mathrm{Cu}^{2+}$ binding to the enzyme was determined to be $22.04 \mu \mathrm{M}$. The decrease of the apparent Michaelis constant $(\mathrm{Km})$ and activation energy values in the presence of $\mathrm{Cu}^{2+}$ correlates well with its activating effect on the acid phosphatase activity. This propriety could be used as
\end{abstract}

C. M. Jonsson ( $\square)$

Embrapa Meio Ambiente, CP 69, Rod. SP 340, Km 127,5, 13820-000 Jaguariúna, São Paulo, Brazil

e-mail: jonsson@cnpma.embrapa.br

H. Aoyama

Departamento de Bioquímica, Instituto de Biologia, Universidade Estadual de Campinas, 13083-970

Campinas, São Paulo, Brazil a sensitive bioindicator for copper in environmental samples.

Keywords Enzyme - Phytoplankton ·

Toxicity $\cdot$ Fungicide $\cdot$ Metal .

Selenastrum capricornutum

\section{Introduction}

There has been an increasing interest in studying the action of metal on enzyme activity and in using their biochemical changes in the aquatic biota as an index of metal toxicity (Lan et al. 1995). In this context, copper, an essential metal ion, has been intensively studied as a potential toxic compound (Gill et al. 1992, Guasch et al. 2002). This element is widely used in agriculture to control fungal diseases and its increasing concentration in the environment has been attributed to mining operations, sewage sludge disposal and industrial discharges (WHO 1998). Copper sulphate has also been used in the control of natural phytoplanktonic communities (Larsen et al. 2003; Le Jeune et al. 2006). The increase of availability and potential toxicity of copper in water may have detrimental effects on aquatic organisms including algae, an important component of primary production and thus the entire aquatic food chain. Algae are able to bioconcentrate and to metabolize 
several aquatic pollutants like insecticides and polycyclic aromatic hydrocarbons (Warshawsky et al. 1995; Jonsson et al. 2001).

Pseudokirchneriella subcapitata (formely Selenastrum capricornutum), an unicellular Chlorophyceae (green) algae present in the freshwater aquatic and terrestrial compartments (Keddy et al. 1995), has been widely used in studies of pollutants effects (Jonsson et al. 1998; Okamura et al. 2002) and is recommended by regulatory national (Gherardi-Goldstein et al. 1990; Jonsson and Maia 1999) and international (OECD 1984) agencies as a test organism.

Acid phosphatase (EC 3.1.3.2) plays important roles in the metabolism such as decomposing organic phosphates into free phosphates and organic compounds. Several functions have been attributed to algae acid phosphatases, such as autophagic digestive processes, hydrolysis of phospholipid materials (Cooper et al. 1974), fertilization (breakdown of plasmalemma and absorption of flagella) (Braten 1975), availability of inorganic phosphate from the extracellular medium (Sommer and Blum 1965), recycling of inorganic phosphate for its reassimilation (Theodorou et al. 1991), endomembrane recycling (Domozych 1989) and spore differentiation (Tsekos and Schnepf 1991). In the freshwater algae $S$. tепиe, the enzyme was found in the cell wall, plasmalemma and vacuole (Michetti et al. 2006). The induction of acid phosphatase activity in unicellular green algae at low $\mathrm{N}$ and $\mathrm{P}$ concentrations has been observed by Kruskopf and Du Plessis (2004).

It has been reported that copper or other metal ion are needed for the catalytic action of different acid phosphatases. Vincent and Averill (1990) have observed that the oxidized form of some mammalian acid phosphatases exhibited a iron-phosphorus interaction indicating that phosphate, and presumably the phosphate esters, bound to one of both irons present in the protein. Reilly et al. (1999) demonstrated that the addition of copper restored nearly all the enzymatic activity of an acid phosphatase from Haemophilus influenzae. The acid phosphatases from the microorganisms Mycoplasma fermentans, Pseudomonas aeruginosa and Yarrowia lipolytica are enhanced in the presence of copper (Domenich et al. 1992; Noda et al. 1994; Ito et al. 2007). This last effect was also observed by Bounias et al. (1996) in the kinetic studies for alkaline and acid phosphatases present in a gut crude extract obtained from honeybees .
The activities of algal enzymes like esterase (Franklin et al. 2001), $\beta$-D-galactosidase (Peterson and Stauber 1996), nitrate redutase, urease, ATPase (Rai and Rai 1997) and antioxidants enzymes (Li et al. 2006) were affected in presence of the metal.

Previously, we reported the activator effect of copper on the activity of acid phosphatase from $P$. subcapitata. Also, we demonstrated that the metal behaved as a slight antagonist for the inhibitor effect of mercury on the enzyme activity (Jonsson and Aoyama 2007). In the present work, we studied the effect of copper ions on the enzyme activity from the algae. We analyzed the stability and determined dose effects and kinetic parameters in order to understand the magnitude and mechanism of metal ion-phosphatase interaction.

\section{Materials and methods}

Materials

$p$-Nitrophenylphosphate ( $p$ NPP) was obtained from Sigma Chemical Co. Stock solutions of $\mathrm{CuSO}_{4} 5 \mathrm{H}_{2} \mathrm{O}$ (Merck) were prepared in Milli-Q water or in liquid medium (OECD 1984). All the other reagents were AR grade.

Organisms and growth conditions

Unicellular green algae Pseudokirchneriella subcapitata was maintained and subcultured in an inorganic liquid medium prepared as recommended by OECD (OECD 1984). Cultures were grown in $250 \mathrm{ml}$ flasks sealed with cotton bungs and containing $200 \mathrm{ml}$ of sterilized medium. The flasks were incubated in a controlled temperature chamber $\left(20 \pm 2{ }^{\circ} \mathrm{C}\right)$ under a continuous white fluorescent light of 3,000-4,000 lux and manually shaken twice a day. Every 40-60 days, a new stock culture maintained at $4{ }^{\circ} \mathrm{C}$ (in dark) was prepared by inoculating approximately $5 \times 10^{4}$ cells $\mathrm{ml}^{-1}$ (Jonsson and Aoyama 2007).

Harvesting and preparation of extracts

All centrifugation procedures were carried out at $4{ }^{\circ} \mathrm{C}$. Exponential phase organisms were harvested by centrifugation at 4,000 r.p.m. for $5 \mathrm{~min}$ in a Beckman J2-21 refrigerated centrifuge (rotor SER\# 7644, 
JA-20) and washed twice with $0.1 \mathrm{M}$ sodium acetate buffer, $\mathrm{pH}$ 5.0. The algae pellet was suspended in $0.1 \mathrm{M}$ sodium acetate buffer $(1: 4 \mathrm{w} / \mathrm{v})$ and the cell suspension was submitted to the cell disruption procedure for phosphatase extraction as described previously (Jonsson and Aoyama 2007): The sample was frozen at $-20^{\circ} \mathrm{C}$, thawed at room temperature and submitted to a probe sonication at $0^{\circ} \mathrm{C}$ (ice bath) for $50 \mathrm{~s}$ followed by $20 \mathrm{~s}$ interval (1 cycle) with an amplitude of 70 (Vibra Cell, Sonics Materials Inc., $45 \mathrm{~mm}$ tipped probe). This procedure was repetead twice. The resultant cell disrupted suspension was centrifuged at 10,000 r.p.m. for $20 \mathrm{~min}$ and the supernatant fluid (extract) was used for acid phosphatase activity determination.

\section{Assay of phosphatase activity}

Acid phosphatase activity was routinely assayed at least in duplicate by incubating the enzyme with $p$ NPP as substrate and measuring the $p$-nitrophenol $(p \mathrm{NP})$ produced as previously described (Prazeres et al. 2004). The enzyme activity was determined in a final volume of $1 \mathrm{ml}$ containing $0.1 \mathrm{M}$ sodium acetate buffer (pH 5.0) and $10 \mathrm{mM}$ substrate. After incubation for $40 \mathrm{~min}$ at $37^{\circ} \mathrm{C}$, the reaction was terminated by the addition of $1 \mathrm{ml}$ of $1 \mathrm{M} \mathrm{NaOH}$. The $p \mathrm{NP}$ released was measured at $405 \mathrm{~nm}$ in a UNICAM 8625 UV/VIS spectrophotometer. For the initial velocity (V) determination, the amount of $p$ NP produced was calculated using a molar extintion coefficient of $18,300 \mathrm{M}^{-1} \mathrm{~cm}^{-1}$ (Chaimovich and Nome 1970). Units (U) of enzymatic activity are defined as $\mu$ moles of $p$ NP released per min.

\section{Effect of $\mathrm{Cu}^{2+}$ concentration}

The enzyme activity was determined in the absence (control) or in the presence of several copper concentrations in a range of $0.1-200 \mu \mathrm{M} \mathrm{Cu}^{2+}$. LineweaverBurk plot was used to determine the $\mathrm{Cu}^{2+}$-enzyme dissociation constant by plotting the velocity change (delta $\mathrm{V}$ ) versus the reciprocal of copper concentration $\left(1 /\left[\mathrm{Cu}^{2+}\right]\right)$, as described by Dixon and Webb (1979).

\section{Enzyme stability}

The enzyme activity was determined after preincubation at $37^{\circ} \mathrm{C}$ for $0,20,40$ and $60 \mathrm{~min}$ in the absence or in the presence of $0.2 \mathrm{mM} \mathrm{Cu}^{2+}$.
Apparent Michaelis constant $(\mathrm{Km})$ and maximum velocity $(\mathrm{Vmax})$ determination

The enzyme was preincubated in the absence or in the presence of $0.2 \mathrm{mM} \mathrm{Cu}^{2+}$, and after that the enzyme activity was determined, using $p$ NPP as substrate, in a concentration range of $0.1-10.0 \mathrm{mM}$. The apparent $\mathrm{Km}$ and Vmax values were calculated from Lineweaver-Burk plot.

\section{Activation energy determination}

The enzyme activity was determined after preincubation at different temperatures $(27,32,37,42$ and $47^{\circ} \mathrm{C}$ ) in the absence or in the presence of $0.2 \mathrm{mM}$ $\mathrm{Cu}^{2+}$. The activation energy values were determined from the slopes of the Arrhenius plots (log V versus 1/T (Kelvin)), according to Dixon and Webb (1979).

Data analysis

The results were analyzed by a Simples Regression program with a Statgraphics ${ }^{\circledR}$ Plus Version 2 software package.

\section{Results}

In vitro effect of copper on $P$. subcapitata acid phosphatase activity

A remarkable increase in $p$ NPP dephosphorylation was observed in the presence of $\mathrm{Cu}^{2+}$ up to a concentration of $0.05 \mathrm{mM}$, when this metal was previously incubated with the enzyme (Fig. 1). The dissociation constant $\left(\mathrm{KdCu}^{2+}\right)$, for the complex $\mathrm{Cu}^{2+}$-enzyme was calculated from the double reciprocal plot to be $22.04 \mu \mathrm{M}$ (Fig. 1, inset). In contrast to the results described in the Fig. 1, no significant enzyme activity changes were observed in the presence of $\mathrm{Cu}^{2+}$ without preincubation (results not shown).

Stability of acid phosphatase in the presence of copper

The enzyme was stable for at least $60 \mathrm{~min}$ at $37^{\circ} \mathrm{C}$ when preincubated in the presence of $0.2 \mathrm{mM} \mathrm{Cu}^{2+}$. In contrast, a loss of acid phosphatase activity of 


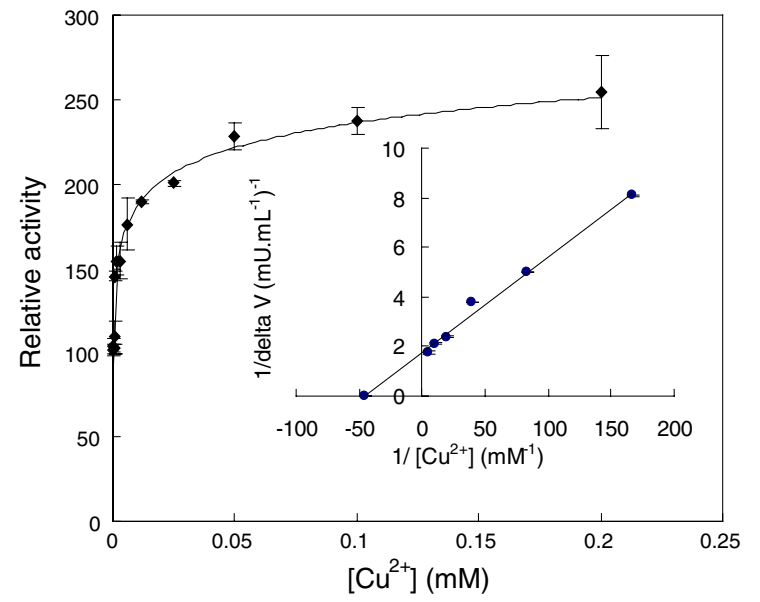

Fig. 1 Effect of copper concentration on acid phosphatase activity. The preincubation of the enzyme and $\mathrm{Cu}^{2+}$ (at different concentrations) was performed for $20 \mathrm{~min}$ at $37^{\circ} \mathrm{C}$. At the end of this period, the reaction was initiated by the addition of $p$ NPP $10 \mathrm{mM}$ as substrate, as described in Methods. The activity in the absence of $\mathrm{Cu}^{2+}$ was considered as $100 \%$ (control) and the other values were determined as percentages of this value. Determination of dissociation constant for the interaction $\mathrm{Cu}^{2+}$-acid phosphatase (inset). Bars represent the standard deviations of the averages of two replicates

about $60 \%$ was observed when the enzyme was preincubated in the absence of the metal ion (Fig. 2).

Effect of $\mathrm{Cu}^{2+}$ on the acid phosphatase

kinetic parameters

The values of apparent $\mathrm{Km}$ and Vmax were determined from the double reciprocal plot of Lineweaver-Burk, and the activation energy from the Arrhenius plot (not shown). These results are shown in the Table 1. In the presence of $0.2 \mathrm{mM} \mathrm{Cu}^{2+}$, the apparent $\mathrm{Km}$ value decreased from 1.21 to $0.37 \mathrm{mM}$ and the activation energy from 26.8 to $13.6 \mathrm{~kJ} \mathrm{~mol}^{-1}$; no significant difference was observed for the Vmax values $\left(0.55\right.$ and $\left.0.75 \mathrm{mU} \mathrm{ml}^{-1}\right)$.

\section{Discussion}

The metallic ion $\mathrm{Cu}^{2+}$ has been generally used in enzymatic systems in order to inactivate the reactions by binding to essential sulfhydryl groups located at or near the active site. In the case of acid phosphatases, we have previously reported that the enzyme purified from bovine kidney (Granjeiro et al. 1997) and from

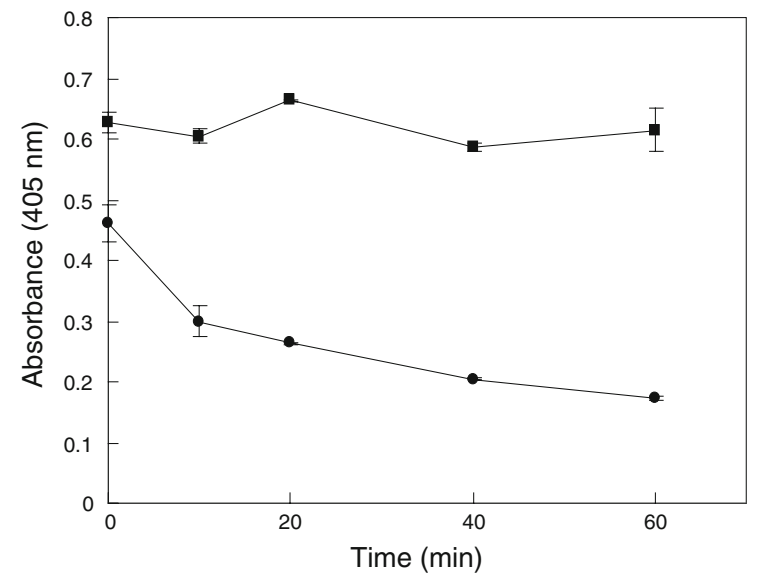

Fig. 2 Preincubation time course of acid phosphatase activity. The enzyme activity was determined at the indicated times by preincubation at $37^{\circ} \mathrm{C}$ in the absence $(\mathbf{)}$ or in the presence ( $\mathbf{\square})$ of $0.2 \mathrm{mM} \mathrm{Cu}^{2+}$. Bars represent the standard deviations of the averages of two replicates

Table 1 Effect of $\mathrm{Cu}^{2+}$ on the kinetic parameters for $P$. subcapitata acid phosphatase $^{\mathrm{a}}$

\begin{tabular}{lcc}
\hline Parameter & {$\left[\mathrm{Cu}^{2+}\right](\mathrm{mM})$} & \\
\hline & 0.0 & 0.2 \\
$\mathrm{Km}(\mathrm{mM})$ & $1.21 \pm 0.42$ & $0.37 \pm 0.05$ \\
Vmax $\left.(\mathrm{mU} \mathrm{ml})^{-1}\right)$ & $0.55 \pm 0.16$ & $0.75 \pm 0.06$ \\
Activation energy $\left(\mathrm{kJ} \mathrm{mol}^{-1}\right)$ & $26.8 \pm 1.5$ & $13.6 \pm 3.9$ \\
\hline
\end{tabular}

${ }^{\mathrm{a}}$ The $\mathrm{Km}$ and Vmax values were determined from Lineweaver-Burk plot and the activation energy from the Arrhenius plot. The standard deviations $( \pm)$ represent the averages of two replicates

castor bean seed (Granjeiro et al. 1999) were inhibited 97 and $93 \%$ in the presence of $10 \mathrm{mM}$ and $1 \mathrm{mM} \mathrm{Cu}^{2+}$, respectively.

In the present work we demonstrated that $\mathrm{Cu}^{2+}$ when preincubated with $P$. subcapitata acid phosphatase activated the $p$ NPP-directed reaction. Lineweaver-Burk plot was used to determine the dissociation constant value for $\mathrm{Cu}^{2+}$ binding to the enzyme $\left(\mathrm{KdCu}^{2+}\right)$, as described by Dixon and Webb (1979) (Fig. 1, inset). Youngs et al. (2000) have also applied this method to determine the dissociation constant for the Cd-Mn-peroxidase complex. The low magnitude of the $\mathrm{KdCu}^{2+}$ value $(22.04 \mu \mathrm{M})$ obtained for the complex $\mathrm{Cu}^{2+}$-acid phosphatase indicated a strong binding capacity of this metal to the enzyme.

Even after preincubation of $\mathrm{Cu}^{2+}$, and enzyme, no activation effect was observed for the acid 
phosphatase obtained from the algae Ochromonas danica (Patni and Aaronson 1974). However, others in vitro studies showed that acid phosphatases from crude extracts of Rizopus delemar (Tsekova and Galabova 2003) and honeybee guts (Bounias et al. 1996) were activated by $\mathrm{Cu}^{2+}$.

In order to explain the reasons for the activation of the $P$. subcapitata acid phosphatase by $\mathrm{Cu}^{2+}$, we performed three different experiments: enzyme stability study, determination of apparent $\mathrm{Km}$, and determination of activation energy, in the absence and in the presence of the metal.

The presence of $\mathrm{Cu}^{2+}$ promoted a protection of the $P$. subcapitata acid phosphatase from thermal inactivation at $37^{\circ} \mathrm{C}$ for at least $1 \mathrm{~h}$ (Fig. 2), which supports an enzyme- $\mathrm{Cu}^{2+}$ interaction. Protection of enzymes by metal ions in stability studies was also described for fungal laccase by $\mathrm{Cu}^{2+}$ (Baldrian and Gabriel 2002), fungal peroxidase by $\mathrm{Cd}^{2+}$ and $\mathrm{Mn}^{2+}$ (Youngs et al. 2000), and E. coli alkaline phosphatase by $\mathrm{Cu}^{2+}$ and other metals (Trotman and Greenwood 1971).

The kinetic parameter apparent $\mathrm{Km}$ for $p \mathrm{NPP}$ decreased (3.3 fold) in the presence of $\mathrm{Cu}^{2+}$ (Table 1), suggesting an enhancement on the affinity enzyme-substrate by copper.

Bounias et al. (1996) also described a decrease of the $\mathrm{Km}$ value for honeybee gut acid phosphatase contained in the crude extract in the presence of copper. The apparent $\mathrm{Km}$ value of $0.37 \mathrm{mM}$, obtained in the presence of $\mathrm{Cu}^{2+}$ is similar to those reported for other algae species when the enzyme was assayed in a non-preincubated system and in the absence of the metal (Bennum and Blum 1966; Patni and Aaronson 1974). The decrease of the activation energy value from 26.8 to $13.6 \mathrm{~kJ} \mathrm{~mol}^{-1}$ in the presence of $\mathrm{Cu}^{2+}$ (Table 1), also contributed to the activating effect of $\mathrm{Cu}^{2+}$ on the $P$. subcapitata acid phosphatase activity.

Summarizing, different factors contributed to the increase in the acid phosphatase activity in the presence of $\mathrm{Cu}^{2+}$ : protection of the enzyme against thermal inactivation, increase in the enzyme-substrate affinity, and reduction of the activation energy. The high sensitivity of the enzyme crude extract to copper may be useful as a tool to detect this metal in natural waters and other environmental samples.

We hope that the results presented in this work can improve the understanding of the basic events of the impact of copper at biochemical levels in primary producer organisms. Moreover, they could provide a sound basis for comparison with enzymatic processes affected by other pollutants.

Acknowledgements This work was supported by grants from Fundação de Amparo à Pesquisa do Estado de São Paulo (FAPESP), Conselho Nacional de Desenvolvimento Científico e Tecnológico (CNPq) and Empresa Brasileira de Pesquisa Agropecuária (Embrapa). The authors are grateful to Dr. Fred Y. Fujiwara (Instituto de Química, UNICAMP) for critically reading the manuscript.

\section{References}

Baldrian P, Gabriel J (2002) Copper and cadmium increase laccase activity in Pleurotus ostreatus. FEMS Microbiol Lett 206:69-74. doi:10.1111/j.1574-6968.2002.tb10988.x

Bennum A, Blum JJ (1966) Properties of the induced acid phosphatase and of the constitutive acid phosphatase of Euglena. Biochim Biophys Acta 128:106-123

Bounias M, Kruk I, Nectoux M, Popeskovic D (1996) Toxicology of cupric salts on honeybees. V. Gluconate and sulfate action on gut alkaline and acid phosphatases. Ecotoxicol Environ Saf 35:67-76. doi:10.1006/eesa.1996.0082

Braten T (1975) Ultrastructural localization of phosphohydrolases in gametes, zygotes and zoospores of Ulva mutabilis FØYN. J Cell Sci 17:647-653

Chaimovich H, Nome F (1970) Purification and properties of an acid phosphatase from bovine brain. Arch Biochem Biophys 139:9-16. doi:10.1016/0003-9861(70)90039-1

Cooper A, Bowen ID, Lloyd D (1974) The properties and subcellular localization of acid phosphatases in the colourless alga Polytomella caeca. J Cell Sci 15:605-618

Dixon M, Webb EC (1979) Enzymes, 3rd edn. Longmans Green and Co Ltd., London

Domenich CEA, Teresita AL, Salvano MA et al (1992) Pseudomonas aeruginosa acid phosphatase: activation by divalent cations and inhibition by aluminium ions. FEBS Lett 299:96-98. doi:10.1016/0014-5793(92)80108-S

Domozych DS (1989) The endomembrane system and mechanism of membrane flow in the green alga, Gloeomonas kupfferi (Volvocales, Chlorophyta) II. A cytochemical analysis. Protoplasma 149:108-119. doi:10.1007/BF0132 2983

Franklin NM, Stauber JL, Lim RP (2001) Development of flow cytometry-based algal bioassays for assessing toxicity of copper in natural waters. Environ Toxicol Chem 20:160170. doi:10.1897/1551-5028(2001)020<0160:DOFCBA > 2.0.CO;2

Gherardi-Goldstein E, Bertoletti E, Zagatto PA et al (1990) Procedimentos para a utilização de testes de toxicidade no controle de efluentes líquidos, Serie Manuais. CETESB, São Paulo

Gill TS, Tewari H, Pande J (1992) Short and long term effects of copper on the rosby barb (Puntius conchonius Ham). Ecotoxicol Environ Saf 23:294-306. doi:10.1016/01476513(92)90079-I

Granjeiro JM, Ferreira CV, Juca MB et al (1997) Bovine kidney low molecular weight acid phosphatase: FMNdependent kinetics. Biochem Mol Biol Int 41:1201-1208 
Granjeiro PA, Ferreira CV, Granjeiro JM et al (1999) Purification and kinetic properties of a castor bean seed acid phosphatase. Physiol Plant 107:151-158. doi:10.1034/ j.1399-3054.1999.100201.x

Guasch H, Paulsson M, Sabater S (2002) Effect of copper on algal communities from oligotrophic calcareous streams. J Phycol 38:241-248. doi:10.1046/j.1529-8817.2002.01114.x

Ito H, Inouhe M, Tohoyama H, Joho M (2007) Effect of copper on acid phosphatase activity in yeast Yarrowia lipolytica. Z Naturforsch [C] 62:70-76

Jonsson CM, Aoyama $\mathrm{H}$ (2007) In vitro effect of agriculture pollutants and their joint action on Pseudokirchneriella subcapitata acid phosphatase. Chemosphere 69:849-855. doi:10.1016/j.chemosphere.2007.06.024

Jonsson CM, Maia AHN (1999) Protocolo de avaliação de agentes microbianos de controle biológico de pragas para registro como biopesticidas. III. Testes em organismos não alvo do ambiente aquático. Serie Documentos. Embrapa Meio Ambiente, Jaguariúna

Jonsson CM, Maia AHN, Ferreira CJA et al (1998) Risk assessment of the herbicide clomazone in the aquatic life. Verh Int Verein Limnol 26:1724-1726

Jonsson CM, Paraiba LC, Mendoza MT et al (2001) Bioconcentration of the insecticide pyridaphenthion by the green algae Chlorella saccharophila. Chemosphere 43:321-325. doi:10.1016/S0045-6535(00)00145-4

Keddy CJ, Greene JC, Bonnel MA (1995) Review of wholeorganism bioassay: soil, freshwater, sediment, and freshwater assessment in Canada. Ecotoxicol Environ Saf 30:221-251. doi:10.1006/eesa.1995.1027

Kruskopf MM, Du Plessis S (2004) Induction of both acid and alkaline phosphatase activity in two green-algae (Chlorophyceae) in low $\mathrm{N}$ and $\mathrm{P}$ concentrations. Hydrobiologia 513:59-70. doi:10.1023/B:hydr.0000018166. 15764.b0

Lan WG, Wong MK, Chen N et al (1995) Effect of combined copper, zinc, chromium and selenium by orthogonal array design on alkaline phosphatase activity in liver of the red sea bream, Chrysophrys major. Aquaculture 131:219230. doi:10.1016/0044-8486(94)00326-J

Larsen DK, Wagner I, Gustavson K et al (2003) Long-term effect of sea-nine on natural coastal phytoplanktonic communities assessed by pollution induced community tolerance. Aquat Toxicol 62:35-44. doi:10.1016/S0166445X(02)00065-6

Le Jeune AH, Charpin M, Deluchat V et al (2006) Effect of copper sulphate treatment on natural phytoplanktonic communities. Aquat Toxicol 80:267-280. doi:10.1016/ j.aquatox.2006.09.004

Li M, Hu C, Zhu Q, Chen L et al (2006) Copper and zinc induction of lipid peroxidation and effects on antioxidant enzyme activities in the microalga Pavlova viridis (Prymnesiophyceae). Chemosphere 62:565-572. doi: 10.1016/j.chemosphere.2005.06.029

Michetti KM, Leonardi PI, Cáceres EJ (2006) Cytochemical localization of acid phosphatase in Stigeoclonium tenue (Chaetophorales, Chlorophyceae). Biocell 30:491-496

Noda M, Shibata K, Sawa Y et al (1994) Purification and characterization of an acid phosphatase from Mycoplasma fermentans. Microbiol Immunol 38:103-107
OECD (1984) Guidelines for Testing of Chemicals. Alga, Growth Inhibition Test. Organization for Economic Cooperation and Development. OECD, Paris

Okamura H, Mingyu P, Aoyama I et al (2002) Algal growth inhibition by river water pollutants in the agricultural area around lake Biwa, Japan. Environ Pollut 117:411-419. doi:10.1016/S0269-7491(01)00196-8

Patni NJ, Aaronson S (1974) Partial characterization of the intra- and extracellular acid phosphatase of an alga, Ochromonas danica. J Gen Microbiol 83:9-20

Peterson SM, Stauber JL (1996) New algal enzyme bioassay for the rapid assessment of aquatic toxicity. Bull Environ Contam Toxicol 56:750-757. doi:10.1007/s001289900110

Prazeres JN, Ferreira CV, Aoyama H (2004) Acid phosphatase activities during the germination of Glycine max seeds. Plant Physiol Biochem 42:15-20. doi:10.1016/j.plaphy. 2003.10.009

Rai PK, Rai LC (1997) Interactive effects of UV-B and Cu on photosynthesis, uptake and metabolism of nutrients in a green alga Chlorella vulgaris under simulated ozone column. J Gen Appl Microbiol 43:281-288. doi:10.2323/ jgam.43.281

Reilly TJ, Chance DL, Smith AL (1999) Outer membrane lipoprotein e (P4) of Haemophilus influenzae is a novel phosphomonoesterase. J Bacteriol 181:6797-6805

Sommer JR, Blum JJ (1965) Cytochemical localization of acid phosphatase in Euglena gracilis. J Cell Biol 24:235-251. doi:10.1083/jcb.24.2.235

Theodorou ME, Elrifi IR, Turpin DH et al (1991) Effect of phosphorus limitation on respiratory metabolism in the green algae Selenastrum minutum. Plant Physiol 95:10891095. doi:10.1104/pp.95.4.1089

Trotman NA, Greenwood C (1971) Effects of zinc and other metal ions on the stability and activity of Escherichia coli alkaline phosphatase. Biochem J 124:25-30

Tsekos I, Schnepf E (1991) Acid phosphatase activity during spore differentiation of the red algae Gigartina teedii and Chondria tenuissima. Plant Syst Evol 176:35-51. doi: 10.1007/BF00937944

Tsekova K, Galabova D (2003) Phosphatase production and activity in copper (II) accumulating Rizopus delemar. Enzyme Microb Technol 33:926-931. doi:10.1016/ j.enzmictec.2003.06.001

Vincent JB, Averill BA (1990) An enzyme with double identity: purple acid phosphatase and tartrate-resistant acid phosphatase. FASEB J 4:3009-3013

Warshawsky D, Cody T, Radike M et al (1995) Biotransformation of benzo[a]pyrene and other polycyclic aromatic hydrocarbons and heterocyclic analogs by several green algae and other algal species under gold and white light. Chem Biol Interact 97:131-148. doi:10.1016/0009-2797 (95)03610-X

WHO (1998) Copper. Environmental health criteria 200. International Programme on chemical safety. World Health Organization, Geneva

Youngs HL, Sundaramoorthy M, Gold MH (2000) Effects of cadmium on manganese peroxidase. Competitive inhibition of MnII oxidation and thermal stabilization of the enzyme. Eur J Biochem 27:1761-1769. doi:10.1046/ j.1432-1327.2000.01173.x 